\title{
The Landscape of Panemunė Castles: Value and Protection Problems
}

\author{
Jūratė Jurevičienė, Marija Burinskienė* \\ Vilnius Gediminas Technical University, Research Institute of Territory Planning, Sauletekio av. 11, Vilnius, Lithuania \\ *Corresponding author: marija.burinskiene@vgtu.lt
}

cross $^{\text {ref }}$ http://dx.doi.org/10.5755/j01.sace.2.3.3981

\begin{abstract}
The article studies historic and cultural value of landscape having formed in the mid-section of the right bank of Nemunas River (between Jurbarkas and Kaunas). The article gives methodological principles and criteria based on which a historic expressiveness of landscape is assessed. A historic value of the study territory is described, also its unique features in the context of Lithuania, and the relevant aspects of cultural cognitive potential. It is revealed that till now the largest attention has been paid to the existing buildings of Panemunè (Gelgaudai, Vytėnai), Raudonè and Raudondvaris residential castles, however, they are only partly integrated into the local social structure. When forming landscape the sites of the former Crusader castles on the Nemunas riverbank, namely Seredžius II (Palocèliai, the supposed site of Dubysenburg) and Dubysa II (Pilaitè) are insufficiently respected. The expressiveness of medieval defensive structures and the spatial interaction of their remains create in the study territory an important but yet unusable potential of mental landscape.
\end{abstract}

Keywords: Panemune castles, Nemunas valley landscape, historic and cultural potential of the territory.

\section{Introduction}

Lithuania has several regions distinguished for their exclusive historic and cultural value. One of those is the valley and its surroundings situated in the middle part of Nemunas River. It is obvious, that Vilnius, Trakai and Kaunas castles in a present-day Lithuanian understanding of historic and cultural heritage were and still are the structures of great significance, having acquired even a status of national symbols. However, the image of midsection of Panemune (the term refers to the territory situated on the bank of Nemunas River) has remained fragmentary and is related only to residential masonry castles built in the Renaissance period and later reconstructed, the role of which in the history of Lithuania was of no particular importance.

The article studies the most valuable features of landscape having formed on the right bank of Nemunas River valley, in the section between Jurbarkas and Kaunas cities. In the article the landscape of this section is termed as the landscape of Panemunè castles with the emphasis on its mental aspect ${ }^{1}$ and a visual domination of three residential masonry castles: Panemune, Raudonè and Raudondvaris. It is believed that landscape, which is formed seeking for sustainability, must integrate and reflect all the layers of historic and cultural value having formed in a course of territorial evolution, paying the largest attention to the most important of them. The article is based on the currently available results of archaeological, historical

1 In article 1 of the European Landscape Convention the landscape is described as part of the land, as perceived by local people or visitors. and architectural investigations of the study area, also on the method of historical reconstruction and the recently implemented exploratory, architectural and landscape investigations ${ }^{2}$.

According to the General Plan of the Territory of Republic of Lithuania the Panemuniai region, based on the character of its cultural values and territorial distribution of the types of accumulation areas, is attributed to one of the five regions of Lithuania with the dominating historical heritage. The plan indicates that the main historical weight in this region is represented by Liškiava, Merkine, Alytus, Punia, Pypliai, Seredžius and Veliuona mounds, Panemuné castles, Kaunas City and Padubysiai archaeological memorial complex (General Plan of the Territory of Republic of Lithuania 2002). However, it could be stated that the current level of exploration of the cultural value of the territory between Kaunas and Jurbarkas does not correspond to its significance being declared. Up to now, only single objects of immovable cultural heritage and some urbanized locations of this area have been studied. Comprehensive and complex investigations from the point of view of heritage protection were carried out only in Panemunè, Raudonè and Raudondvaris castles. Historians and archaeologists have made several studies of the Lithuanian and Crusader castle sites that have not survived on the right bank of the Nemunas River, however, no systematic territorial investigations

\footnotetext{
2 In 2012, the VGTU Territorial Planning Institute started implementing a scientific research project "Innovative Regeneration Methods of Architectural Heritage: Panemunè Castles", supported by the Research Council of Lithuania (project No. VAT-12053).
} 
were implemented. Though the former territorial system of defensive fortifications, created by Lithuanians during the Lithuanian-Teutonic wars, has been mentioned in the works of many historians, the exact site and the evolution of important parts of the system have not been known yet (Kvizikevičius 2003). Insufficient historical investigations create preconditions for studying only the separate aspects of the cultural value of this landscape.

\section{Research methodology}

In a present-day postmodern society the value of landscape is sought to be unclosed in various aspects. In various European countries, when studying a particular case of landscape, depending on its origin, context, the problem to be analysed and the aim of work, several models are often applied. If still two decades ago when studying landscape the largest attention was paid for identifying the historic and architectural significance of buildings and their ensembles of exclusive value, at this time the largest importance is attached to the landscape as a whole in order to emphasize interaction between its separate parts. The object to be protected is often termed as the whole environmental fabric making the landscape. A special importance is also given to the subjective values of site identity. Since landscape heritage is the result of the past cultural human activities and the creation of today's cultural and social opinions, its origin is sometimes termed as "doubly cultural" (Fairclough 2008).

In Lithuania, in the works related to the landscape problems landscape is still understood as a territorial analogue or even as the whole of its missing greenery. However, another attitude is being gradually established that the value for landscape, as for any other object, is given by society, and the protection of its cultural value in all its forms grows from the values assigned to it by the users of the territory - "how much and how we would talk about the surrounding universe and its features, essentially, we talk about the fact of how we perceive it" (Zaleckis 2011). One of the aims of the European Landscape Convention related to the cultural heritage protection is to assess the landscapes defined depending on the particular values assigned to them by the interested parties and the population concerned. A strategy of creating democratic environment requires giving a possibility to local communities to express their opinion about the cultural value of the environment.

The Burra Charter has given a recognizing that cultural importance of building or site was extended to its setting, its contents and the knowledge that pertained to it. It emphasized that "cultural significance is embodied in the place itself, its fabric, setting, use, associations, meanings, records, related places and related objects" (ICOMOS Australia, 1999). In Lithuania, a mental aspect of landscape conception has been legitimated in the currently-valid regulations of international level (European Landscape Convention 2010, article 1a), however, it is only fragmentary reflected in the national legal acts regulating territorial management. Definitions of landscape, given in the national legal acts, do not reveal its nature - landscape is described as a territorial combination of natural and (or) anthropogenic components of the land surface, whereas, cultural landscape is defined as a landscape created by human activities and reflecting its coexistence with the environment (Law on Protected Areas of the Republic of Lithuania 2001, Law on Protection of Immovable Cultural Heritage of the Republic of Lithuania 2004), or a landscape purposefully formed and satisfying the needs of biological, psychological (information, aesthetic), social, ergonomic (suitability to the activities) or economic environmental quality in living, working and recreation (the List of Landscape Policies of the Republic of Lithuania 2004). Different documents of territorial planning of Lithuania give references to the territorial coherence of landscape's material parts (general plans of the Republic of Lithuania or of different municipalities, special plans of protected areas), however, investigations of landscape as of a mental object are still left for the future, and no general methodology for investigating this field has been developed.

In an emotional reflection of landscape a symbolic value is interlaced with historic, associative and aesthetic aspects. Recently, it is more often spoken about "spirit of place" (genius loci), though there is neither its research methodology nor the obligation to study it when preparing territorial planning documents. Lithuania in this respect is not an exception - no exact criteria for the conformity of genius loci to the list of the World Heritage have been formulated (Cleere 1995). In Lithuania, state and municipal institutions could act as the organizers of special plans for landscape development, but because of expensive and longlasting process the plans are initiated only in exceptional cases.

Landscape in this research is studied as a field of interaction between its territorial elements, components and functional sociotopes. The main approach is that an integral unity of landscape components is one of the underlying peculiarities of its cultural value determined by the landscape origin itself. Also, a methodical approach is used that historical value is not stable, it is necessary to expand it with new aspects - a valuable object shall be not only old but also shall preserve for the past and living generations the memory of important (i.e. selected) past events (Fish 2008).

The paper studies both the present and the fragmentary survived or unrecognizably extinct spatial, semantic and functional relations between residential, defensive and communication infrastructure objects. Taking into account that the study region is attributed to one of the five regions of historical domination in Lithuania and following a methodical approach of the end of the 20th century that when aiming at adaptability of work results it is advisable to analyse the most relevant and problematic elements and relations of the system (Leach 2000), this work studies no other material and functional objects of the landscape.

For the research the nested analysis method $^{3}$ was chosen, more and more often used in studying cultural phenomena. It allows distinguishing the most relevant at the time being cultural value aspects of the study landscape without seeking for systematic perfection of research. In order to reveal the cultural value a diachronic investigation

\footnotetext{
3 A cultural philosopher Nerijus Milerius describes this research method as "nest in a nest".
} 
was used to define the changes in Panemune landscape in the period of essential historical breaks of the region: in the 14th and 15th century, in the 19th century and in the beginning of the 20th century, in Soviet times and today. The currently started inquiry of the residents of Raudone settlement, the aim of which is to find out what aspects of the living environment, functions, cultural values are the most important for the local residents and how they are related to the castles, is supposed to correct the research results of Panemunè landscape cultural value.

\section{Cultural value and adjustment for tourism}

The most attractive tourism objects in Panemune region still remain the masonry castles. Castles are considered the main tourist attraction objects also in other European countries. Already the Romanticism epoch has attached to the medieval castles the significance of conveyor of European cultural identity. Though each of medieval castles in Europe had its own distinctive features of use and purpose, they always expressed the power and territorial control of the seignior (Creighton 2005) - the features that stimulate their visitors to become identified with the castles. In Lithuania, during the period of overdue Romanticism those attributes of value were transferred to the nation. Already since the end of the $19^{\text {th }}$ century people searched in landscape for the relics reflecting the national ideals. However, the buildings of Panemune, Raudone or Raudondvaris castles, representing by their architecture the already post-Vytautas the Great period not related to the fights with crusaders, were reflected in the Lithuanian fiction, publications, arts and photography not so vividly and unambiguously symbolically as Vilnius, Trakai or Kaunas castles. The masonry castles of Panemune region did not become an integral and unambiguous part of the majestic past of Lithuania. A famous Lithuanian writer Jonas Biliūnas, when describing his impressions of the journey along Nemunas River in 1905, wonders and asks: “....and there peeps out from between the forest a manor or an old and already decrepit tower reminding by its crenelated peak that of a fortress of medieval ages, - a great while stands on a steep riverbank and finally vanishes beyond... And once again there comes an idea: for what purpose the tower has been built?..".

In the study territory, Panemune, Raudone and Raudondvaris residential castles are up to now the main architectural objects due to their volume, scale and dominating position in the territorial silhouettes and perspective views that open from the main approaches. For the visitors, travelling along the former Samogitian (Žemaičių) road or coming from the northward settlements, the views of the castles are not obscured by other structures. The parks surrounding all the three castles isolate them from the adjacent settlements that still preserve plenty of objects of ancient architecture as well as low-value Soviet buildings. The existing road network of the study territory also proves that the complexes of castles are poorly integrated into the common transport and communication structure.

The research showed that a conditional expressiveness of territorial isolation of castle complexes can be related also to the social isolation of the castles. Panemune Castle, having three high and the northern one-storey (not restored) blocks forming a close courtyard and accessed only through the northern gates of the castle, is connected to the adjacent settlement by only one minor road. The castle, in contrast to the adjacent buildings of Vytenai Silesian Monastery, by the purposes of its use is not adjusted for local community needs, though it holds a variety of cultural public events organized by the Vilnius Academy of Arts (the user of the castle). The ensemble of Raudone buildings, comprised of the palace and the mill, is a partially open structure of volumes which, having found itself on the edge of existing settlement, is connected to its residential zone by two streets. Though surrounded by the park from three sides, the castle ensemble is integrated into the structure of settlement spaces. The building of the former Raudone Palace is occupied by the elementary school of the settlement which, though being at risk to be closed due to a decreasing number of pupils, is used for various events of local community. It's hardly credible that castle is part of a mental landscape of the local residents - over the last several years, during consideration of various territorial planning documents in Jurbarkas Municipality, no responses or requests of the local residents have been received related to Panemunè or Raudonè castles. The buildings of Raudondvaris Castle complex, though also surrounded by the park from three sides, create a structure of volumes open to the environment. The Raudondvaris complex, functionally divided by different users, serves various purposes (from the use for representative national celebrations to residential purpose), however, the cultural events held there are also visited by the local residents, and the park often hosts the community feasts.

The increase of the number of visitors and activities in the castles meets the expectations of the local residents to have more possibilities for jobs near their home. From this point of view, the national and local interests are promoting each other. It is supposed that in future the interpreted history of the castles will play a more important role in the mental landscape of the local communities. One can guess also that local "humble values" will deserve more attention of the tourists.

The current research showed that the archaeological value of the area has not been properly represented. A unique component of the cultural landscape of Panemunè area - the remains of the former Crusader castles - is not included into the list of the cultural heritage objects protected by State and is not adjusted for visitors. Though "landscape is one of the main three (next to the written and archaeological) sources of knowledge of the past" (Vaitkevičius 2010) no investigations have been made yet to determine what was the interaction between the Crusader castles, the so-called motte and bailey castles, built on the Nemunas riverbank to block the Lithuanian Veliuona and Seredžius castles and the other defensive and auxiliary buildings and surrounding settlements. Territorial interaction between the defensive buildings and fortifications, built by Lithuanians and Crusaders in the pre-Christian period, is not seen, though based on the medieval logic of defence the functioning castles had to be surrounded with wide open spaces created by felling. At present, the other objects of archaeological heritage having survived in this area are also not indicated - 


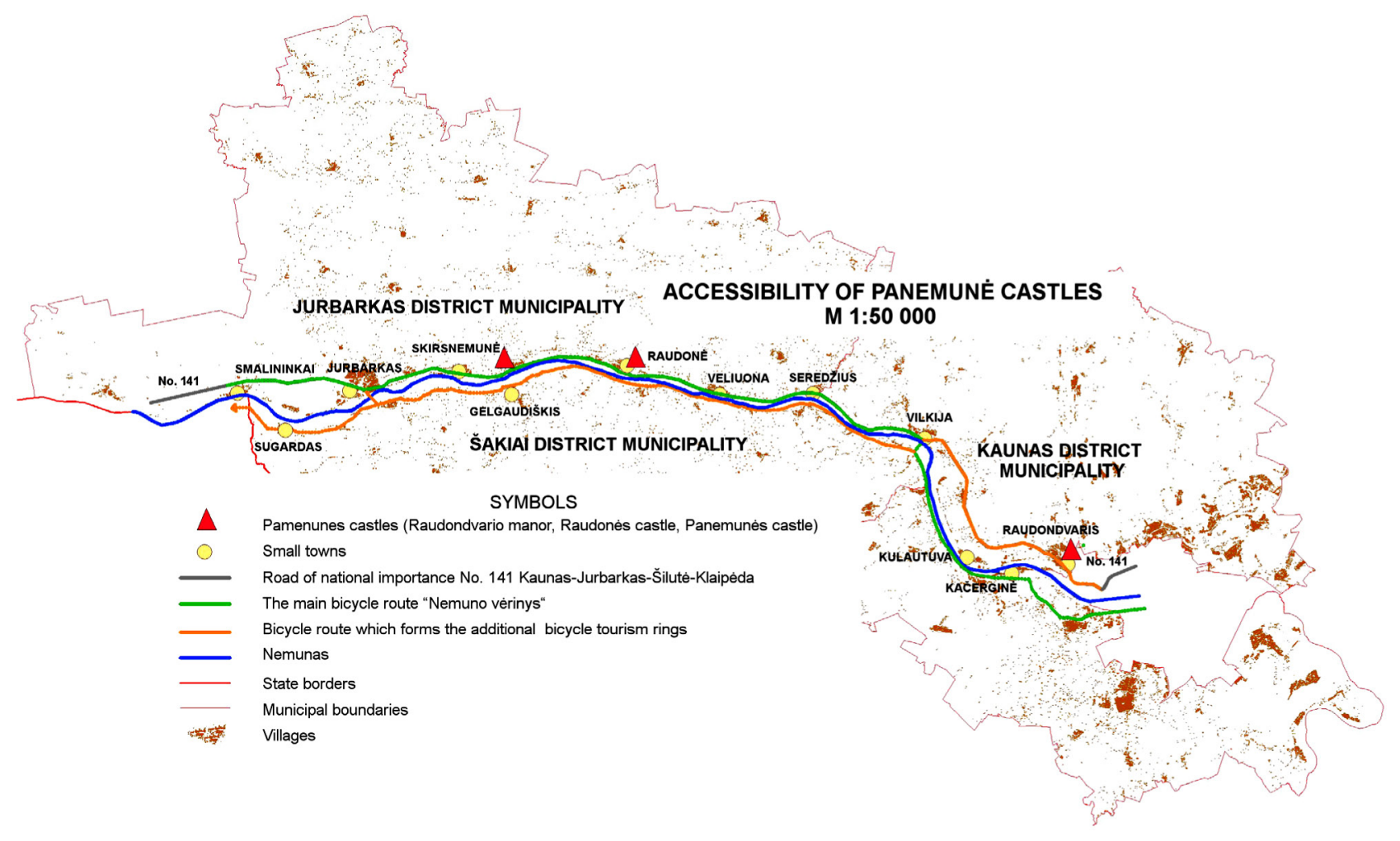

Fig. 1. The accessibility of Panemune castles by land and waterways

the sites of former settlements or burial-grounds. Though Panemunè, Raudonè and Raudondvaris castles were studied by archaeologists in different periods, as Rasa Čepaitiene (2004) states, "today archaeology becomes attractive and popular also due to the fact that its material reflects a daily life of simple people - our ancestors". This layer of archaeological heritage in the study region has not been properly discovered and interpreted.

Typological structure of landscape elements can be methodically changed. In respect of rearrangement possibilities, it is important to determine the "tolerance limits" of changes. In the territory of Raudone Castle a graveyard has still survived with a monument for the Soviet soldiers killed in 1941-1944, the adjacency of which reduces the value of both the castle ensemble and the graveyard.

In the framework of Panemune Cycle Route Project it is planned to join to one system the already built segments of Panemunè cycle route in Šakiai and Jurbarkas regions. In Jurbarkas region it is planned to build the cycle track which will run from Raudonè to Seredžius. The partially constructed cycle route creates possibilities to feel a variation of close and open spaces, a variety of castles, settlements and natural views, creates preconditions to emphasize an emotional suggestibility of the landscape. A properly selected place for the track allows creating a landscape plot close to baroque aesthetics and expanding in time - having mounted up to Raudone settlement a view of the castle is unclosed, further, when driving several kilometres along the slope of Kartupenai Mound the landscape of Nemunas riversides is gradually showed up. Having passed nine kilometres from Raudone the cycle track curves uphill to the Panemune Castle Park, behind which a view of Šiline
Inn suddenly appears. At Žvyriai, behind the oak grove, the cycle track turns to Skirsnemune settlement, at Molyne village goes down to Nemunas and on its eight kilometres way to Jurbarkas the track winds through the open Nemunas riverbank.

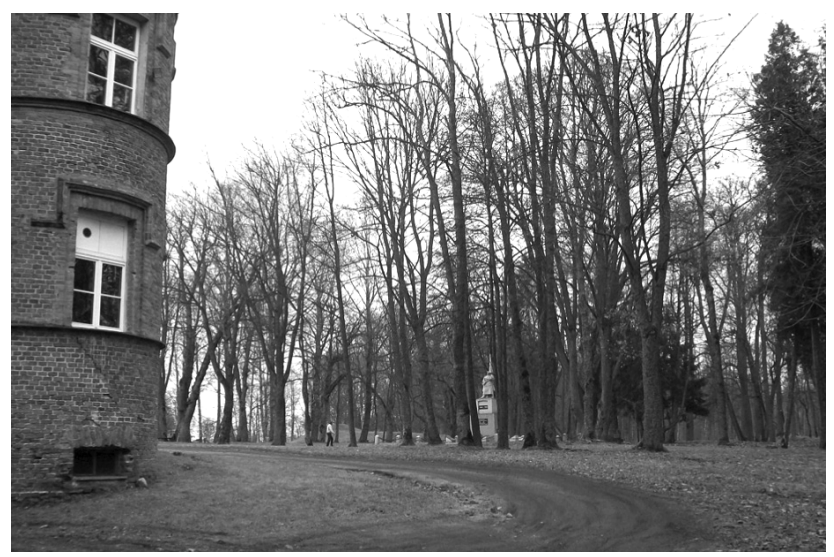

Fig. 2. The north-eastern tower of Raudone Castle and the graveyard of the Soviet soldiers planned to be removed from the park of the castle

In the territory, the major part of which is covered with forests and parks, formation of spacious visual relations is a continuous task of territorial management and supervision. The Plan of Panemuniai Regional Park Management anticipates unclosing the objects and views of natural and cultural heritage with the help of felling. Currently, one of the most important mounds in the history of Lithuania Kartupenai Mound with an ancient settlement which is also the site of the Bisene Castle, known as the very first 
Lithuanian castle to have been attacked and burnt down by the Crusaders - has not been yet adjusted for observation and visiting, though it has survived in the adjacency of Panemune Castle (the mound's visual protection zone borders the defined territory of Panemune Castle). A similar situation could be found at Raudonenai Mound with the settlement, the mounds of Jautakiai and Ringove and Belvederis defensive fortification which are still overgrown with forest. However, the concrete solutions of the territorial management, the places and volumes of felling, and the access and observation sites could be determined only having implemented a complex investigation of natural and cultural values of the territory and of their presentation possibilities.

Territorial infrastructure of the area of Panemune castles creates preconditions to present landscape in a different way and enables to unclose and perceive the different aspects of its value. There are preconditions to form the view of the area in a linear time, comprising the complexes of Panemunè, Raudonè and Raudondvaris castles situated on the left bank of Nemunas, the already unclosed for observation Seredžius and Veliuona mounds, Pilaičiai and Palocèliai sites of an ancient castles. The riverbank and the southern valley of Nemunas was an especially attractive place for creating ancient settlements. It remained vital also in later times and in the beginning of Soviet period. At present, the riverbank is almost unused, almost dead and shrubby, and the former relationship between the settlements and the riverbank are cut. Already in the last century, when during reconstruction the Samogitian (Žemaičių) road was heightened, a functional as well as a spatial relationship between the settlements and the Nemunas was lost. Under the project "Construction of Mobile Piers for the Development of Nemunas Touring Route", implemented in the framework of the National Investment Promotion Program by Alytus District Municipality, Šakiai District Municipality and Kaunas District Municipality, the mobile piers were constructed in Vilkija, Kulautuva, Zapyškis and Raudondvaris settlements. Though large European Union funds were invested into the infrastructure of inland waterways, navigation in Nemunas River is still stagnant.

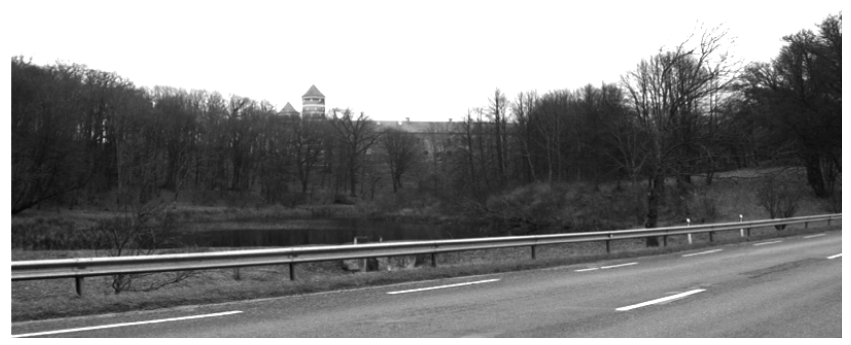

Fig. 3. A view of Panemune Castle from the road Kaunas Klaipeda. In 2011, with the help offelling the fragmentary views of the castle were opened

In recent years, a number of important works were implemented to restore and adjust the cultural heritage of Panemune area. From the point of view of visual relations and cultural value of landscape one of the most significant works was the elimination of critical condition of Raudone Castle Tower and restoration of its masonry - in 2005 the tower was re-opened for the visitors to observe the Nemunas valley. Many valuable aspects of the landscape of Nemunas valley, representing integral interaction of history and natural values, still remain unclosed, however, with many regrets for insufficiently used possibilities to rapidly develop mass tourism, for the meantime one can be glad of avoiding aggressive commercialization impact on the authenticity of surroundings.

From the point of view of physical condition of castle buildings the largest danger for them is caused by moisturemoisture-related problems cannot be solved locally in each building but only by assessing them all in a context of landscape. A complex of Raudondvaris Castle structures was formed on a clayey hill situated on the top of Nevėžis valley. The surface has been changed several times, however a high groundwater was always a big problem for construction activities (Bertašius 2011). Sources of moisture, worsening the condition of buildings of Panemune and Raudone castles, are not only the pedestals of manor walls covered with excess soil in Soviet times when levelling courtyards, but also the culverts of ponds having seen no repairs for a long time, as well as the trees growing close to the manor walls and casting a shadow on the buildings.

Local communities, used to live in Panemune area, have been disappearing like in other Lithuanian villages. With the decreasing number of children the building of Raudone Castle will be forced to look for another user. However, the adjustment of high cultural value landscape merely for the purposes of visiting tourism and not for the needs of local community can result not in its revival but in irreversible degradation processes of the cultural value of landscape.

\section{Conclusions}

1. In Lithuania, a general methodology for identifying valuable features of historic and cultural landscape has not been yet developed. No consequent studies have been taken to examine the expressiveness of the cultural value of landscape in the dominating regions of Lithuanian historic heritage. Territorial coherence of the material parts of landscape is considered in several territorial planning documents, however, no fundamental scientific research is currently carried out to study landscape as a mental object.

2. The mid-section of Panemune is a unique representer of two military systems of the 13th-15th century: the aggressive Teutonic and the defensive Lithuanian. The landscape of the right riverbank section between Jurbarkas and Kaunas still reflects a distinct semantic and spatial composite interaction of Lithuanian defensive castles, their contraposition to the Teutonic castles used to be built on the riverbank, and the authenticity of local natural components. Those territorial features create in the context of Lithuania the exclusive historic and cultural value of the study territory and shall be treated as the essential resource for the development of cultural tourism.

3. At present, the main works of restoration, adjustment and renovation of the mid-section of Panemune are carried 
out in the residential masonry castles situated in the upper terrace of the Nemunas slope: Panemune (Gelgaudai, Vytènai), Raudone and Raudondvaris castle complexes. The lowest amount of works is being implemented in the ensemble of Raudone Castle, the building of the former palace of which is the only castle building used for direct needs of local community. Whereas, in Panemune Castle, distinguished for its exclusively high architectural and historic value, the currently implemented multi-stage project of its adjustment for tourism needs is not intended for the development of interaction between the castle and the local community and for the strengthening of the castle's integration into the local social structure.

4. A contraposition of Lithuanian and Crusader castles and the former tension between them has not been properly represented in the territory. The importance of the territory, as of a unique East European medieval military theatre having personified one and a half hundred years of Lithuanian resistance to Crusader expansion, has not been emphasized. When forming the territory the insufficient role is given to the forms of local terrain and to the survived defensive structures and their relics. Due to insufficient historic and archaeological research the sites of the ancient Crusader castles are not unambiguously localised, their supposed sites are not visually emphasized.

5. The current multiple transport and communication infrastructure of the territory (the former Samogitian (Žemaičiu) road, local roads, cycle track (with two operating sections), pedestrian tracks and Nemunas River piers) creates preconditions to develop a complicated mental landscape based on a developing plot. By opening the views on the castles from the main observation places, by strengthening spatial relations between Lithuanian castles and the sites of the ancient Crusader castles and using additional information and interpretation measures the historic and cultural potential of this landscape would be comprehensively disclosed. With rapid changes in the social structure and the system of values of both the tourists and the Panemune region inhabitants it is necessary to seek for the new ways of cognition and propagation of a cultural value of this unique landscape by also involving local communities into the heritage protection processes.

\section{References}

Almonaitis V. 2003. Vokiečių ordino Dubysos pilis. Seredžius. Vilnius, Versmè.

Bertašius M. 2011. Raudondvario dvaro sodyba. In: Archeologiniai tyrinèjimai Lietuvoje 2011 metais. Vilnius, Lietuvos archeologijos draugija, 243-246.

Biliūnas J. 2007. Ir rados stebuklas. Vilnius, Lietuvos rašytoju sajungos leidykla.
Burra Charter: The Australia ICOMOS Charter for Places of Cultural Significance. 1999. Australia ICOMOS, available at: http://australia.icomos.org/wp-content/uploads/BURRA CHARTER.pdf (accessed 29 March 2013).

Cleere H. 1995. Cultural landscapes as World Heritage. Conservation and management of archaeological sites, 1(1), 63-6.

Creighton O. H. 2005. Castles and landscapes. Power, community and fortification in Medieval England. London, Equinox Publishing.

Čepaitienè R. 2004. Nuo Indianos Džons iki Laros Kroft arba kintantis praeities vaidmuo šiandienos pasaulyje. Miestu praeitis, 1, 7-41.

European Landscape Convention. 2000. Council of Europe. Available at: http://conventions.coe.int/Treaty/Commun/ QueVoulezVous.asp?NT=176\&CM=8\&CL=ENG (accessed 29 March 2013).

Fairclough G. 2008. New heritage, an introductory essay - people, landscape and change. In Fairclough G., Harrison R., Jameson J. H. Jnr., Schofied J. The heritage reader. London, Routledge, 297-312.

Fish S. 2008. Administration of historical heritage in Germany: a national report. In: Fish S. National approaches to the governance of historical heritage over time. A comparative report. Amsterdam, NLD: IOS Press.

Jurbarko rajono 2011-2015 metu starteginis pletros planas (patvirtintas Jurbarko rajono savivaldybės tarybos $2010 \mathrm{~m}$. rugsėjo 30 d. sprendimu Nr. T2-270). Available at: http:// www.jurbarkas.lt/index.php?1517086044 (accessed 29 March 2013).

Jurbarko rajono savivaldybès teritorijos bendrasis planas, patvirtintas Jurbarko rajono savivaldybès tarybos $2008 \mathrm{~m}$. kovo 27 d. sprendimu Nr. T2-81, teritorijų planavimo dokumentų registro registracijos Nr. 000941000643.

Kvizikevičius L. 2003. Seredžius archeologijos šaltinių duomenimis. In: Lietuvos valsčiai. Seredžius. Vilnius, Versmè, 117-124.

Leach N. 2000. Rethinking architecture. London and New York, Routledge.

Lietuvos Respublikos kraštovaizdžio politikos krypčiu aprašas. Žin., 2004, 174-6443, 6 str.

Lietuvos Respublikos Nekilnojamojo kultūros paveldo apsaugos istatymas, Žin., 2004, Nr. 153-5571.

Lietuvos Respublikos Saugomų teritoriju istatymo pakeitimo istatymas, Žin., 200112 28, Nr. 108-3902; Žin., 201006 22, Nr. 81-4229.

Lietuvos Respublikos teritorijos bendrasis planas. LR Seimo nutarimas Nr. IX-1154, $2002 \mathrm{~m}$. spalio $29 \mathrm{~d}$.

Panemunių regioninio parko tvarkymo planas, patvirtintas Lietuvos Respublikos aplinkos ministro 2010 m. birželio 14 d. įsakymu Nr. D1-499.

Vaitkevičius G., Kiškienė M. L. 2010. Kreivasis miestas. 2010. In: Miestų praeitis 2, Vilnius. LII.

Zaleckis K. 2011. Globalizacijos atspindžiai miesto kūne: keletas ¡žvalgų. Logos, 66, 142-152. 
Jūratė JUREVIČIENĖ - researcher, Vilnius Gediminas Technical University, Research Institute of Territory Planning. Main research area: research in cultural heritage.

Address: Sauletekio av. 11, Vilnius, Lithuania.

Tel.: (8 5) 2745210

E-mail: jurate.jureviciene@vgtu.lt

Marija BURINSKIENE் - professor, Vilnius Gediminas Technical University, Research Institute of Territory Planning. Main research area: urban planning.

Address: Sauletekio av. 11, Vilnius, Lithuania.

Tel.: $\quad$ (8 5) 2744720

E-mail: marija.burinskiene@vgtu.lt 